Jurnal Insan Farmasi Indonesia, 3(2) Desember 2020 (261-270)

Eka Kumalasari

p-ISSN 2621-3184 ; e-ISSN 2621-4032

doi: 10.36387/jifi.v3i2.584

\title{
UJI AKTIVITAS ANTIBAKTERI EKSTRAK ETANOL DAUN BAWANG DAYAK (Eleutherine palmifolia (L.) Merr) TERHADAP PERTUMBUHAN Propionibacterium acne
}

\author{
Eka Kumalasari ${ }^{*}$, Aina, Noverda Ayuchecaria, Noor Aisyah \\ Sekolah Tinggi Ilmu Kesehatan ISFI Banjarmasin \\ *: ekakumalasari260989@gmail.com
}

\begin{abstract}
ABSTRAK
Jerawat yang muncul dapat mengakibatkan perubahan wajah, berupa bengkak, kemerahan, bernanah dan menimbulkan rasa sakit sehingga akan menimbulkan kesan yang kurang menarik dalam penampilan dan mempengaruhi kecantikan seseorang. Penyebab jerawat salah satunya ada aktivitas Propionibacterium acne. Daun bawang dayak merupakan salah satu tanaman yang mengandung senyawa antibakteri. Aktivitas antibakteri tanaman ini perlu dikaji melalui penelitian menggunakan metode sumuran, dengan kelompok ekstrak dengan berbagai konsentrasi, kelompok kontrol positif (klindamisin 0,1\%) dan kelompok kontrol negatif (Aquadest). Hasil penelitian menunjukan bahwa ekstrak etanol daun bawang dayak memiliki aktivitas antibakteri terhadap pertumbuhan Propionibacterium acne. Diameter zona hambat yang terbentuk pada konsentrasi 20\%, 40\%, 60\%, 80\% dan 100\% masing-masing 7,25 mm (sedang), 10,43 mm (kuat), 15,23 mm (kuat), 18,55 mm (kuat) dan 22,20 mm (sangat Kuat).
\end{abstract}

Kata kunci: Zona hambat, Daun Bawang Dayak, Propionibacterium acne

\section{ABSTRACT}

Acne that appears can cause facial changes, in the form of swelling, redness, purulence and causing pain so that it will create an impression that is less attractive in appearance and affects one's beauty. One of the causes of acne is Propionibacterium acne. Dayak onion leaves are one of the plant that contain antibacterial compounds. The purpose of this study was to determine the antibacterial activity of ethanol extract of onion leaves on the growth of Propionibacterium acne.The antibacterial activity of this plant needs to be reviewed through with extract group with various concentrations, positive control group (clindamycin 0.1\%) and negative control group (Aquadest). The results showed that the ethanol extract of dayak onion leaves had antibacterial activity against the growth of Propionibacterium acne. The diameter of the inhibition zone formed at concentrations of 20\%,40\%,60\%,80\% and 100\% respectively $7.25 \mathrm{~mm}$ (medium), $10.43 \mathrm{~mm}$ (strong), $15.23 \mathrm{~mm}$ (strong), 18, $55 \mathrm{~mm}$ (strong) and 22.20 mm (very strong).

Keywords: Inhibition zone, Dayak onion leaves, Propionibacterium acne 
Jurnal Insan Farmasi Indonesia, 3(2) Desember 2020 (261-270)

Eka Kumalasari

p-ISSN 2621-3184 ; e-ISSN 2621-4032

doi: $10.36387 /$ jifi.v3i2.584

\section{PENDAHULUAN}

Banyak factor yang menyebabkan kulit berjerawat salah satunya adalah adanya aktivitas bakteri Propionibacterium acnes Bakteri Propionibacterium acnes ini menyebabkan terjadinya inflamasi pada minyak yang terkumpul dikulit ${ }^{1}$.

Solusi untuk mengatasi jerawat salah satunya adalah dengan antibiotic $^{2}$. Menurut Lood (2011) membuktikan $\quad 50 \% \quad$ isolat Propionibacterium acnes berbagai strain dari pasien berjerawat resisten terhadap antibiotik klindamisin dan eritromisin, dan $20 \%$ dari isolat resisten terhadap tetrasiklin ${ }^{3}$. Oleh sebab itu untuk mencegah terjadinya resistensi bakteri terhadap antibakteri perlu dikembangkan penelitian dalam penemuan obat baru yang berasal dari alam. Pencarian senyawa antibakteri alami yang tidak menimbulkan dampak negatif terhadap manusia, yaitu dengan memanfaatkan zat aktif pembunuh bakteri yang terkandung dalam tanaman ${ }^{4}$.

Daun bawang dayak adalah salah satu tanaman yang berpotensi sebagai antibakteri. Dilihat dari skrining fitokimia, ekstrak etanol $70 \%$ daun bawang dayak mengandung flavonoid, saponin, fenolik dan tanin. Komponen bioaktif tersebut memiliki mekanisme kerja dalam menghambat pertumbuhan bakteri dan diharapkan daun bawang dayak dapat memiliki aktivitas dalam menghambat pertumbuhan Propionibacterium acne bakteri penyebab jerawat ${ }^{5}$.

\section{METODE PENELITIAN}

$\underline{\text { Alat }}$

Alat-alat yang digunakan yaitu timbangan analitik, alat-alat gelas, jarum ose, oven, autoklaf, laminary air flow, mikroskop, cawan petri/petridish, erlenmeyer, inkubator, pembakar bunsen, mikropipet, jangka sorong,

$\underline{\text { Bahan }}$

Bahan-bahan yang digunakan yaitu daun bawang dayak, bakteri Propionibacterium acne, Nutrient Agar (NA), aquadest, klindamisin, pereaksi lieberman-burchard, etanol $70 \%, \quad \mathrm{NaCl} \quad 0,9 \%, \quad$ pereaksi Dragendorff, pereaksi Mayer, larutan $\mathrm{FeCl}_{3}$, asam asetat, kapas, $\mathrm{HCl}$ pekat dan amoniak.

$\underline{\text { Pembuatan ekstrak }}$ 
Eka Kumalasari

p-ISSN 2621-3184; e-ISSN 2621-4032

doi: $10.36387 /$ jifi.v3i2.584

Tanaman bawang dayak diperoleh dari perkebunan di Petuk Ketimpun, Palangka Raya, Kalimantan Tengah. Daun bawang dayak dikeringkan menjadi simplisia dan di haluskan hingga menjadi serbuk. Pembuatan ekstrak dilakukan dengan metode maserasi. Sampel sebanyak 500 gram dimasukkan ke dalam wadah toples kaca, lalu ditambahkan etanol 70\% 2,5 liter dan dibiarkan selama 2-3 hari sambil sesekali diaduk. Hasil ekstraksi kemudian disaring dan filtrat diuapkan menggunakan rotary evaporator pada suhu $45-50^{\circ} \mathrm{C}$ hingga diperoleh ekstrak cair. Ekstrak cair dipekatkan menggunakan water bath sehingga diperoleh ekstrak kental.

\section{$\underline{\text { Skrining Fitokimia Ekstrak }}$}

1. Uji Flavonoid

Sebanyak 1 mg ekstrak dilarutkan dengan etanol $70 \%$ kemudian larutan diteteskan diatas kertas saring, selanjutnya kertas diuapi dengan ammonia. Jika terbentuk wara kuning menunjukan positif flavonoid ${ }^{6}$.

2. Uji Saponin
Sebanyak 1 mg ekstrak dilarutkan dengan aquadest kemudian ditambah $10 \mathrm{ml}$ air panas dinginkan dan kemudian kocok kuat-kuat selama 10 detik. Jika positif maka sampel akan berbuih yang tidak menghilang selama 10 menit dengan tinggi buih 1-10 cm menunjukkan adanya saponin

3. Uji Alkaloid

Sebanyak 1 mg ekstrak dilarutkan dengan etanol 70\% ditambahkan $0,5 \mathrm{ml} \mathrm{HCl}$ dan larutan dibagi menjadi 2 tabung. Tabung 1 ditambahkan 2-3 tetes reagen dragendorf, tabung 2 ditambahkan 23 tetes reagen meyer. Hasil positif alkaloid jika terbentuk endapan berwarna merah bata, merah, jingga (dengan reagen dragendorf) dan endapan putih atau kekuningkuningan (dengan reagen mayer) menunjukan adanya alkaloid ${ }^{7}$.

4. Uji Tanin

Sebanyak 1 mg ekstrak dilarutkan dengan etanol 70\% kemudian ditambahkan larutan $\mathrm{FeCl}_{3}$ 2-3 tetes, jika timbul warna hijau kehitaman atau biru tua menunjukkan adanya tanin?

5. Uji Fenol 
Jurnal Insan Farmasi Indonesia, 3(2) Desember 2020 (261-270)

Eka Kumalasari

p-ISSN 2621-3184 ; e-ISSN 2621-4032

doi: $10.36387 /$ jifi.v3i2.584

Sebanyak 1 mg ekstrak dilarutkan dengan etanol $70 \%$ kemudian ditambahkan dengan $1 \mathrm{ml}$ larutan $\mathrm{FeCl}_{3}$ Jika terbentuk warna biru tua, biru kehitaman atau hitam kehijauan menunjukkan adanya senyawa polifenol dan $\operatorname{tanin}^{7}$.

Pengujian aktivitas antibakteri ekstrak

Pengujian aktivitas antibakteri dilakukan replikasi sebnayak 4 kali. Sebanyak $20 \mathrm{ml}$ media NA dimasukkan ke dalam cawan petri. Kemudian sebanyak $100 \mu$ l suspensi Propionibacterium acne dimasukkan kedalam cawan petri, Buat sumuran dengan alat pelubang sumuran. Masukkan $100 \mu 1$ larutan uji berbagai konsentrasi $20 \%, 40 \%, 60 \%$, dan $80 \%$ dan $100 \%, 100 \mu \mathrm{l}$ kontrol negatif (aquadest), $100 \mu \mathrm{l}$ kontrol positif (klindamisin) selanjutnya Inkubasi pada suhu $37^{\circ} \mathrm{C}$ selama $24 \mathrm{jam}$. Amati dan ukur diameter zona hambatnya menggunakan jangka sorong.

\section{HASIL DAN PEMBAHASAN}

Daun yang diperoleh di keringkan dan diekstraksi dengan metode maserasi. Metode maserasi dipilih karena senyawa yang diduga terkandung di daun bawang dayak

seperti flavonoid, tanin, fenol, steroid, triterpenoid alkaloid dan saponin tidak tahan terhadap pemanasan. Sehingga diharapkan senyawa yang terkandung didalamnya stabil dan tidak akan rusak.

Pelarut yang digunakan adalah etanol $70 \%$ karena bersifat semi polar. Pelarut etanol memiliki dua sisi yang terdiri dari gugus -OH yang bersifat polar dan gugus $\mathrm{CH}_{2} \mathrm{CH}_{3}$ yang bersifat non polar, sifat non polar inilah yang membuat etanol mampu menarik kandungan alkaloid, tritepenoid dan steroid di dalam daun bawang dayak secara optimal serta sifat polar inilah yang membuat etanol mampu menarik kandungan senyawa tanin, fenol, dan flavonoid yang juga termasuk senyawa polar sehingga mampu mengekstraksi kandungan senyawa di dalam daun bawang dayak secara optimal menggunakan pelarut polar ${ }^{8}$. Etanol juga mempunyai titik didih yang rendah, tidak beracun dan tidak berbahaya serta pelarut etanol $70 \%$ mempunyai sifat sebagai antiseptik, sehingga diharapkannya dalam proses maserasi selama 3 hari tidak ada pertumbuhan bakteri. Ekstrak yang 
Jurnal Insan Farmasi Indonesia, 3(2) Desember 2020 (261-270)

Eka Kumalasari

p-ISSN 2621-3184 ; e-ISSN 2621-4032

doi: $10.36387 /$ jifi.v3i2.584

dihasilkan berwarna coklat pekat, kertas saring berubah warna menjadi rasa pahit dan berbau tajam dengan nilai rendemen ekstrak terhadap bobot simplisia yang diperoleh adalah $20,74 \%$.

Hasil skrinning firokimia menunjukkan bahwa ekstrak etanol daun bawang Dayak mengandung senyawa flavonoid, saponin, tanin, alkaloid, dan polifenol. Pada uji alkaloid diperoleh hasil positif, Hasil positif alkaloid menggunakan reagen Dragendorf karena ion logam $\mathrm{K}^{+}$ membentuk ikatan kovalen koordinasi dengan alkaloid sehingga membentuk kompleks kaliumalkaloid yang mengendap. Hasil positif alkaloid pada uji Mayer ditandai dengan terbentuknya endapan putih. Diperkirakan endapan tersebut merupakan kompleks kalium-alkaloid. Nitrogen pada alkaloid akan bereaksi dengan ion logam $\mathrm{K}+$ dari kalium tetraiodomerkurat (II) membentuk kompleks kalium-alkaloid yang mengendap ${ }^{9}$.

Pada uji flavonoid diperoleh hasil positif dengan melewatkan ekstrak yang telah diteteskan diatas kertas saring dengan uap amonia, kuning. Hal ini karena terjadi reaksi flavonoid dengan uap amonia membentuk garam dan membentuk struktur kinoid pada cincin B yang akan membuat ikatan rangkap terkonjugasi menjadi lebih panjang sehingga akan meningkatkan intensitas warnanya ${ }^{10}$

Uji polifenol diperoleh hasil positif dengan menambah pereaksi $\mathrm{FeCl}_{3}$ membentuk warna larutan biru gelap $^{11}$. Hal ini menunjukkan bahwa ekstrak etanol daun bawang dayak positif mengandung senyawa fenolik. Perubahan warna menjadi biru gelap disebabkan oleh terbentuknya ikatan kovalen koordinasi antara ion besi (III) dengan gugus $\mathrm{OH}$ fenolik ${ }^{9}$.

Uji saponin yang dilakukan dengan menggojok kuat ekstrak daun bawang dayak yang telah dilarutkan dalam aquadest membentuk buih setinggi kurang lebih 1-3 cm dari permukaan. Hal ini menunjukan bahwa serbuk dan ekstrak etanol daun bawang dayak mengandung senyawa saponin. Saponin memiliki gugus hidrofilik dan hidrofob, saat digojog gugus hidrofil akan berikatan dengan air sedangkan gugus hidrofob akan 
Jurnal Insan Farmasi Indonesia, 3(2) Desember 2020 (261-270)

Eka Kumalasari

p-ISSN 2621-3184 ; e-ISSN 2621-4032

doi: $10.36387 /$ jifi.v3i2.584

berikatan dengan udara sehingga membentuk buih ${ }^{11}$

Pada uji tanin diperoleh hasil positif dengan menambahkan $\mathrm{FeCl}_{3}$ membentuk larutan warna hijau kehitaman. Hal ini menunjukan bahwa serbuk dan ekstrak etanol daun bawang dayak mengandung senyawa tanin. Terbentuknya warna hijau kehitaman pada serbuk dan ekstrak disebabkan karena tanin akan membentuk senyawa kompleks dengan ion $\mathrm{Fe} 3+{ }^{12}$. Pada uji steroid menunjukan hasil positif dengan menambahkan $\mathrm{CH}_{3} \mathrm{COOH}$ dan $\mathrm{H}_{2} \mathrm{SO}_{4}$ menghasilkan warna biru kehitaman. Hal ini menunjukan bahwa serbuk dan ekstrak etanol daun bawang dayak mengandung senyawa steroid.

Aktivitas antibakteri dari ekstrak etanol daun bawang dayak terhadap pertumbuhan Propionibac terium acne ditandai dengan adanya zona bening pada media NA. Media pertumbuhan bakteri menggunakan media NA karena NA merupakan media umum untuk menumbuhkan bakteri dan mengembangbiakkan bakteri.

Metode uji sumuran dipilih karena Propionibacterium acne bersifat anaerob fakultatif yang bisa hidup dengan udara atau tanpa udara. Pemilihan metode juga dilihat dari kelarutan ekstrak daun bawang dayak yang diperoleh larut didalam pelarutnya yaitu aquadest sehingga larut atau tidaknya ekstrak tidak mempengaruhi dalam metode sumuran ini. Jika ekstrak larut maka penggunakan metode sumuran ini lebih efektif karena metode sumuran mekanisme kerjanya adalah kontak langsung dengan media tidak dengan perantara seperti (kertas cakram) sehingga bisa lebih efektif dalam menarik zat aktif penghambat pertumbuhan bakteri, sedangkan jika ekstrak tidak larut dalam pelarutnya metode kertas cakram dikhawatirkan kurang efektif karena kurang terdistribusinya zat aktif dalam media. Mekanisme kerja kertas cakram tidak secara langsung kontak dengan media melainkan melalui perantara kertas cakram dengan menyedot cairan zat aktif ataupun pelarutnya.

Pemilihan klindamisin sebagai kontrol positif bertujuan untuk 
Eka Kumalasari

p-ISSN 2621-3184 ; e-ISSN 2621-4032

doi: $10.36387 /$ jifi.v3i2.584

melihat kondisi zona bening yang menunjukan adanya hambatan aktivitas antibakteri dan kontrol negatif menggunakan aquadest pro injeksi untuk melihat kondisi jika tidak ada zona bening yang menunjukan tidak adanya hambatan aktivitas antibakteri. Kontrol positif digunakan adalah obat antibiotik klindamisin dengan konsentrasi yang diujikan $0,1 \%$ sedangkan kontrol negatif menggunakan aquadest pro injeksi. Pemilihan antibakteri klindamisin tergolong spektrum sempit yang berarti aktif pada bakteri gram positif atau bakteri gram negatif saja, serta klindamisin memiliki aktivitas yang tinggi terhadap berbagai bakteri fakultatif anaerob dan organisme gram positif yang rentan terhadap klindamisin salah satunya adalah Propionibacterium acne yaitu bakteri penyebab jerawat ${ }^{13}$. Berikut hasil uji aktivitas antibakteri ekstrak etanol daun bawang Dayak.

pembanding yaitu klindamisin karena

Tabel 1 Hasil uji aktivitas antibakteri ekstrak etanol daun bawang Dayak.

\begin{tabular}{|c|c|c|c|c|c|c|}
\hline \multirow{2}{*}{$\begin{array}{l}\text { Perlakuan } \\
\text { Konsentrasi }\end{array}$} & \multicolumn{4}{|c|}{ Diameter $((\mathrm{H}+\mathrm{V}) / 2)-5 \mathrm{~mm})$} & \multirow{2}{*}{$\begin{array}{c}\text { Rata-rata } \\
\text { Diameter } \\
(\mathbf{m m}) \pm \mathbf{S D}\end{array}$} & \multirow[t]{2}{*}{ Klasifikasi } \\
\hline & $\mathbf{R} 1$ & $\mathbf{R 2}$ & R3 & R4 & & \\
\hline $100 \%$ & 22,20 & 22,20 & 22,10 & 22,20 & $22,20 \pm 0,050$ & Sangat kuat \\
\hline $80 \%$ & 18,50 & 18,55 & 18,55 & 18,60 & $18,55 \pm 0,040$ & Kuat \\
\hline $60 \%$ & 15,20 & 15,20 & 15,30 & 15,25 & $15,23 \pm 0,047$ & Kuat \\
\hline $40 \%$ & 10,45 & 10,40 & 10,40 & 10,50 & $10,43 \pm 0,047$ & Kuat \\
\hline $20 \%$ & 7,30 & 7,25 & 7,2 & 7,25 & $7,25 \pm 0,040$ & Sedang \\
\hline Kontrol positif & 24,5 & 24,60 & 24,60 & 24,60 & $24,53 \pm 0,025$ & Sangat Kuat \\
\hline Kontrol negatif & 0 & 0 & 0 & 0 & 0 & Tidak ada \\
\hline
\end{tabular}

Keterangan :

$\mathrm{R}=$ Replikasi

$\mathrm{H}=$ Diameter Horizontal

$\mathrm{V}=$ Diameter Vertikal

Hasil penelitian menunjukan semakin besar konsentrasi ekstrak etanol daun bawang dayak, semakin besar pula diameter zona hambat yang dihasilkan terhadap acne. Meningkatnya konsentrasi zat menyebabkan meningkatnya kandungan senyawa aktif yang berfungsi sebagai antibakteri, sehingga kemampuannya dalam pertumbuhan Propionibacterium 
menghambat suatu bakteri juga semakin besar.

Zona hambatan yang terbentuk pada semua kelompok perlakuan ekstrak etanol daun bawang dayak ini menunjukkan bahwa terdapat daya hambat terhadap pertumbuhan Propionibacterium acne yang diperkuat dengan hasil skrinning kandungan zat aktif untuk memastikan senyawa yang terkandung dalam ekstrak etanol daun bawang dayak. Hasil pengujian yang dilakukan mengandung senyawa alkaloid, flavonoid, tanin, steroid, saponin dan fenol yang berdasarkan penelitian sebelumnya senyawa tersebut memiliki daya hambat sebagai antibakteri ${ }^{14}$.

Mekanisme kerja senyawa flavonoid sebagai antibakteri adalah membentuk senyawa kompleks dengan protein ekstraseluler dan terlarut sehingga dapat merusak membran sel bakteri dan diikuti dengan keluarnya senyawa intraseluler ${ }^{15}$. Kadar flavonoid pada ekstrak etanol $70 \%$ daun bawang dayak sebesar $34,08 \%{ }^{16}$. Mekanisme kerja senyawa alkaloid dalam menghambat pertumbuhan bakteri adalah dengan cara mengganggu komponen penyusun peptidoglikan pada sel bakteri, sehingga lapisan dinding sel tidak terbentuk secara utuh dan menyebabkan kematian sel tersebut ${ }^{11}$.

Mekanisme kerja senyawa saponin sebagai antibakteri adalah menurunkan tegangan permukaan sehingga mengakibatkan naiknya permeabilitas atau kebocoran sel dan mengakibatkan senyawa intraseluler akan keluar. Mekanisme kerja polifenol sebagai antibakteri berperan sebagai toksin dalam sitoplasma, merusak dan menembus dinding sel serta mengendapkan protein sel bakteri ${ }^{17}$.

Mekanisme kerja steroid sebagai antibakteri yaitu dengan merusak membran lipid, sehingga liposom mengalami kebocoran ${ }^{18}$. Steroid juga diketahui dapat berinteraksi dengan membran fosfolipid, karena sifatnya yang permeabel terhadap senyawasenyawa lipofilik menyebabkan integritas membran menurun dan morfologi membran sel terganggu yang mengakibatkan sel mengalami lisis dan rapuh ${ }^{19}$. Mekanisme kerja 
senyawa tanin sebagai antibakteri adalah menghambat enzim reverse transkriptase dan DNA topoisomerase sehingga sel bakteri tidak dapat terbentuk

\section{KESIMPULAN}

Berdasarkan hal tersebut diatas bahwa ekstrak etanol $70 \%$ daun bawang dayak memiliki aktivitas antibakteri terhadap pertumbuhan Propionibacterium acne dengan diameter zona hambat yang berbedabeda dipengaruhi oleh konsentrasi larutan ekstrak etanol 70\% daun bawang dayak yang digunakan. Semakin tinggi konsentrasi ekstrak etanol 70\% daun bawang dayak maka semakin besar diameter zona hambat terhadap pertumbuhan

Propionibacterium acne.

\section{UCAPAN TERIMA KASIH}

Terima kasih kepada mahasiswa dan rekan penelitian yang telah membantu menyelesaikan penelitian ini dengan baik.

\section{DAFTAR PUSTAKA}

1. Marselia, S, Wibowo, M.A, Arreneuz, S, 2015, 'Aktivitas Antibakteri Ekstrak (Ploiarium alternifolium Melch) Terhadap Propionibacterium acnes',
Skripsi, Universitas Tanjungpura, Pontianak.

2. Lestari, $Y$, Ardiningsih, $P$, Nurlina, 2016, 'Aktivitas Antibakteri Gram Positif Dan Negatif Dari Ekstrak Dan Fraksi Daun Nipah (Nypa fruticans Wurmb.) Asal Pesisir Sungai Kakap Kalimantan Barat, Skripsi, Universitas Tanjungpura, Pontianak

3. Lood, Rolf, 2011, Propionibacterium acnes and its Phages. Department of clinical sciences, Faculty of Medicine, Lund University, Sweden.

4. Khunaifi, M, 2010, 'Uji Aktivitas Antibakteri Ekstrak Daun Binahong (Anredera cordifolia (Ten.) Steenis) Terhadap Bakteri Staphylococcus aureus dan Pseudomonas aeruginosa, Skripsi, Fakultas Sains Dan Teknologi Universitas Islam Negeri Maulana Malik Ibrahim, Malang.

5. Isnindar, Setyowati, E. P., dan Wahyuono, S., 2011, Aktivitas Antioksidan Daun Kesemek (Diospyros kaki L.F) dengan Metode DPPH (2,2-Difenil-1 Pikrilhidrazil), Majalah Obat Tradisional, 16 (2) 63-67.

6. Wardhani, L.K.A dan Sulistyani, N, 2012, 'Uji Aktivitas Antibakteri Ekstrak Etil Asetat Daun Binahong (Anredera Scandens (L.) Moq.) Terhadap Shigella Flexneri Beserta Profil Kromatografi Lapis Tipis', Jurnal Ilmiah Kefarmasian, Vol. 2, No.1.

7. Latifah, 2015, 'Identifikasi Golongan Senyawa Flavonoid dan Uji Aktivitas antioksidan Pada Ekstrak Rimpang Kencur (kaempferia galanga l.) dengan metode dpph (1,1-difenil-2- 
pikrilhidrazil)',

Skripsi,

Universitas Islam Negeri Maulana Malik Ibrahim, Malang.

8. Rahmi, dkk, 2013, 'Profil Fitokimia Metabolit Sekunder Dan Uji Aktivitas Antioksidan Tanaman Jeruk Purut (Citrus histix DC) dan Jeruk Bali (Citrus maxima (Burm.f.)Merr), Universitas Andalas. Padang.

9. Risky, T.A dan Suyatno, 2014, 'Aktivitas Antioksidan Dan Antikanker Ekstrak Metanol Tumbuhan Paku Adiantum Philippensis L' UNESA Journal of Chemistry Vol. 3 No. 1.

10. Robinson, T., 1995, Kandungan Organik Tumbuhan Tinggi, Edisi VI, Hal 191-216, ITB, Bandung.

11. Kumalasari, E, Sulistyani, N, 2011, 'Aktivitas Antifungi Ekstrak Etanol Batang Binahong (Anredera Cordifolia (Tenore) Steen.) Terhadap Candida Albicans Serta Skrining Fitokimia, Skripsi,Universitas Ahmad Dahlan Yogyakarta, Yogyakarta.

12. Effendy, 2007, Perspektif Baru Kimia Koordinasi, Bayumedia Publishing, Malang.

13.Goldstein L.B, 2007, 'Contemporary Reviews in Cardiovascular Medicine Acute Ischemic Stroke, American Heart Association. 116: 1504-1514.

14. Sundu, R, Sapri, Handayani, F, 2018, 'Uji Aktivitas Antibakteri Ekstrak Etanol Umbi Paku Atai Merah (Angiopteris ferox Copel) Terhadap Propionibacterium acnes', Jurnal Medical Sains 2 (2), $75-82$.

15. Bobbarala, V, 2012, 'Antimicrobial Agents. Croatia: Intech. Chusnie, T.T.P, 'Antimicrobial activity of flavonoid', Publishing Process Manager Vedran Greblo, Croatia.

16. Kumalasari, Eka, M. Ahlun Nazir, Aditya Maulana Perdana Putra. 2018. Penetapan Kadar Flavonoid Total Ekstrak Etanol 70\% Daun Bawang Dayak (Eleutherine palmifolia L.) Dengan Metode Spektrofotometri Uv-Vis . Jurnal Insan Farmasi Indonesia. 1(2) 201209

17. Rosidah, A.N, Lestari, P.E, Astuti, P, 2014, 'Daya Antibakteri Ekstrak Daun Kendali (Hippobroma longiflora [L] G. Don) Terhadap Pertumbuhan Streptococcus mutans', Skripsi, Universitas Jember.

18. Madduliri, Suresh, Rao, K, Babu, Sitaram, B, 2013, In vitro evaluation of five Indegenous plants extract Againts five bacterial Phatogens of Human. International Journal of Pharmacy and Phrmaceutical Science 5(4) : 679-684.

19. Ahmed, Bahar. 2007. Chemistry Of Natural Products. New Delhi: Departemen of Pharmaceutical Chemistry of Science. Jamia Hamdard. 